\title{
Model Penentuan Lot Pemesanan Dengan Mempertimbangkan Unit Diskon dan Batasan Kapasitas Gudang dengan Program Dinamis
}

\author{
Dana Marsetya Utama \\ Jurusan Teknik Industri, Fakultas Teknik, Universitas Muhammadiyah Malang \\ Jl. Raya Tlogomas 246 Malang, Jawa Timur, Indonesia, 65144 \\ Surel:dana@umm.ac.id
}

\begin{abstract}
The classical model of dynamic programming in determining the economical lot size of orders generally considers the cost of orders and inventory costs. However, firms are often confronted with the situation of determining the number of economic orders if the seller gives incremental discounts to the buyer and limits the warehouse capacity. In this paper, explains the model of determining lot order by considering discount and limitation of warehouse capacity with dynamic program. The dynamic program model is compared with the Economic Order Quantity (EOQ) model considering the discount and the limitation of warehouse capacity. The comparison result shows that dynamic programming model can minimize total inventory cost compared to EOQ.
\end{abstract}

Keywords: Lot pemesanan, unit diskon, program dinamis, persediaan

\begin{abstract}
Abstrak
Model klasik program dinamis untuk penentuan jumlah pemesanan ekonomis umumnya hanya mempertimbangkan biaya pesan dan biaya persediaan. Namun, perusahaan sering mengalami situasi penentuan jumlah pemesanan ekonomis apabila penjual memberikan potongan harga bertahap (incremental) kepada pembeli dan batasan kapasitas gudang. Dalam paper ini, menjelaskan model penentuan lot pemesanan dengan mempertimbangkan diskon dan batasan kapasitas gudang dengan program dinamis. Model program dinamis tersebut dibandingkan dengan model Economic Order Quantity (EOQ) dengan mempertimbangkan diskon dan batasan kapasitas gudang. Hasil perbandingan didapatkan bahwa model program dinamis dapat meminimalisasi total biaya persediaan dibandingkan dengan EOQ.
\end{abstract}

Kata kunci: Lot ordering, discount units, dynamic programs, inventory

\section{Pendahuluan}

Bahan baku merupakan faktor utama perusahaan untuk menunjang kelancaran proses produksi baik dalam perusahaan besar maupun perusahaan kecil. Penyediaan bahan baku di setiap perusahaan harus terlebih dahulu merencanakan berapa jumlah yang harus dibeli. Pengelolaan bahan baku yang digunakan perusahaan sering didefinisikan sebagai persediaan. Persediaan adalah sebagai bahan yang disimpan dalam gudang untuk kemudian digunakan atau dijual [1]. Bagi perusahaan yang memiliki strategi make to stock, persediaan dapat memberikan dampak besar pada penetapan harga dari produk ataupun keuangan perusahaan [2]. Persediaan perlu dikelola dengan baik sehingga diperoleh kinerja yang optimal [3]. Persediaan dapat ditemui dalam beberapa kategori di antaranya persediaan berdasarkan aspek fungsional dan persediaan berdasarkan aspek fisik, persediaan berdasarkan lamanya waktu penyimpanan [4].

Komponen persediaan terdiri atas permintaan, pemesanan kembali dan pembatas atau kendala. Komponen biaya yang dapat digunakan dalam sistem 
persediaan yaitu di antaranya biaya pembelian (purchase cost), biaya pemesanan (order cost atau setup cost), biaya simpan (holding cost) [5]. Fungsi-fungsi persediaan adalah melakukan "decouple" perusahaan dari fluktuasi permintaan dan menyediakan persediaan barang-barang yang akan memberikan pilihan bagi pelanggan, Mengambil keuntungan dari diskon kuantitas karena pembelian dalam jumlah besar dapat mengurangi biaya pengiriman barang, melindungi terhadap inflasi dan kenaikan harga [6]. Potongan harga sering dijumpai dalam sistem penjualan, baik penjualan produk maupun jasa. Terdapat dua jenis potongan harga yang biasa digunakan yaitu potongan harga kumulatif (all units) dan potongan harga bertahap (incremental). Potongan harga bertahap (incremental) dimaksudkan agar pembeli dapat meningkatkan jumlah pembeliannya. Ditinjau dari sudut pandang pembeli, adanya potongan harga yang ditawarkan penjual mengakibatkan perlunya modifikasi pada sistem persediaan, yaitu dalam menentukan ukuran pemesanan ekonomis berdasarkan pertimbangan potongan harga [7]. Jumlah kuantitas pemesanan yang besar pada saat mendapatkan diskon akan berdampak pada besarnya biaya penyimpanan. Permasalahan persediaan akan semakin kompleks bila terdapat kendala seperti keterbatasan investasi, keterbatasan luas gudang, keterbatasan peralatan/equipment dan ketersediaan item yang akan dibeli [4]. Pembatas-pembatas tersebut akan memengaruhi kuantitas order untuk setiap item.

Masalah yang terjadi adalah perusahaan sering dihadapkan dalam situasi penentuan jumlah pemesanan yang ekonomis apabila penjual memberikan potongan harga bertahap (incremental) kepada pembeli. Namun sering kali pihak manajemen membatasi kuantitas pemesanan dengan mempertimbangkan kapasitas gudang yang dimiliki perusahaan. Penelitian mengenai penentuan lot pemesanan optimal dengan mendapatkan unit diskon atau batasan kapasitas telah dilakukan secara intensif oleh beberapa peneliti. Metode penentuan ukuran lot pemesanan dengan mempertimbangkan unit diskon umumnya yang digunakan adalah Economic Order Quantity (EOQ). Penggunaan EOQ dengan unit diskon terbukti efektif dalam penentuan jumlah pemesanan [7-10]. Perhitungan penentuan lot pemesanan yang optimal dengan mempertimbangkan kapasitas juga dapat menggunakan metode EOQ [11]. Selain penggunaan metode EOQ, penentuan jumlah pemesanan yang ekonomis dapat menggunakan metode program dinamis, metode program dinamis memberikan total biaya yang lebih optimal [12]. Program dinamis juga dapat digunakan dengan mempertimbangkan batasan kapasitas. Metode program dinamis dengan batasan kapasitas gudang akan memberikan total biaya yang minimal $[13,14]$. Program dinamis dengan mempertimbangkan unit diskon lebih optimal jika dibandingkan dengan EOQ [15].

Berdasarkan uraian diatas, banyak penelitian penentuan jumlah pemesanan ekonomis dengan menggunakan EOQ dan program dinamis. Namun, penelitian umumnya hanya mempertimbangkan unit diskon ataupun batasan kapasitas gudang. Penelitian ini bertujuan untuk mendapatkan model penentuan lot pemesanan dengan mempertimbangkan unit diskon dan batasan kapasitas gudang dengan program dinamis. Program dinamis yang digunakan adalah pengembangan model algoritma Wagner Within. Metode penentuan jumlah pemesanan bahan baku yang akan digunakan adalah metode program dinamis yang dikenal dengan Algoritma Wagner Within (WW), yang memiliki karakteristik yang berbeda. Metode WW bertujuan untuk mendapatkan strategi pemesanan optimum dengan jalan meminimalisasi biaya pemesanan dan biaya simpan. Jumlah pemesanan dan waktu pemesanan tidak tetap. Metode ini menetapkan bahwa tidak melakukan pemesanan selama masih ada persediaan atau pemesanan dilakukan setelah persediaan berjumlah nol pada akhir 
periode perencanaan [4]. Penggunaan metode Wagner Within dapat meminimasi biaya yang dikeluarkan perusahaan dari segi biaya persediaan $[16,17]$. Penentuan jumlah pemesanan bahan baku metode WW umumnya hanya mempertimbangkan kendala kapasitas gudang ataupun unit diskon. Penentuan jumlah pemesanan dengan kendala unit diskon dan kapasitas gudang diperlukan pengamatan yang seksama agar menghasilkan solusi yang optimal. Untuk menentukan besarnya pemesanan dilakukan perhitungan pengendalian persediaan dengan mempertimbangkan kendala unit diskon dan kapasitas gudang dengan menggunakan model pengembangan dari model program dinamis algoritma Wagner Within (WW). Pengembangan Model WW dengan kendala unit diskon dan kapasitas gudang diharapkan mencari solusi pemecahan untuk penentuan lot pemesanan yang optimal.

\section{Metode Penelitian}

Total biaya persediaan tahunan merupakan penjumlahan dari biaya-biaya berikut: biaya pembelian, biaya pesan, biaya simpan [4]. Formula matematis untuk menghitung total biaaya persediaan tahunan dapat dilihat pada persamaan 1 .

$T A C=O C+P C+I C$

Pers (1)

Metode algoritma program dinamis yang digunakan penelitian ini mengembangkan dari algoritma Wagner Within (WW). Algoritman WW menggunakan pendekatan programa dinamis dan menghasilkan solusi optimal [4]. Langkah-langkah dalam Algoritma WW yang dikembangkan dengan mempertimbangkan kendala unit diskon dan kapasitas gudang ini adalah sebagai berikut:

1. Hitung matriks total biaya variabel (biaya pesan dan biaya simpan) untuk seluruh alternatif order di seluruh horison perencanaan yang terdiri dari $\mathrm{N}$ periode. Definisikan Zce sebagai total biaya variabel (dari Periode c sampai Periode e) bila order dilakukan pada Periode c untuk memenuhi permintaan Periode c sampai Periode e. Rumusan Zce tersebut adalah sebagai berikut:

$$
Z_{c e}=C+I * P j \sum_{i=c}^{e}\left(Q_{c e} \quad Q_{c i}\right)+Q_{c e} * P j \quad \text { untuk } 1 \leq \mathrm{c} \leq \mathrm{e} \leq \mathrm{N} \quad \text { Pers (2) }
$$

Dengan

$$
Q_{c e}=\sum_{k=c}^{e} D_{k}
$$

2. Periksa nilai $Q_{\text {ce }}$ dengan syarat nilai $Q_{c e}$ tidak melebihi kapasitas gudang $\left(Q_{c e} \leq\right.$ Kapasitas_gudang)

3. Hilangkan total biaya variabel (Zce) yang melebihi kapasitas gudang.

4. Definisikan fe sebagai biaya minimum yang mungkin dalam Periode 1 sampai Periode e, dengan asumsi tingkat persediaan di akhir Periode e adalah nol. Algoritma mulai dengan $\mathrm{f} 0=0$ dan mulai menghitung secara berurutan $\mathrm{f} 1, \mathrm{f} 2, \ldots$, fN. Nilai fN adalah nilai biaya dari pemesanan optimal.

$$
f_{e}=\operatorname{Min}\left\{Z_{c e}+f_{c-1}\right\} \text { untuk } \mathrm{c}=1,2, \ldots, \text { e. }
$$

Pers (3)

Interpretasikan $\mathrm{fN}$ menjadi ukuran lot dengan cara sebagai berikut:

$$
f_{N}=Z_{w N}+f_{w-1} \quad \text { Pemesanan-terakhir dilakukan pada }
$$

Periode w untuk memenuhi permintaan dari Periode $\mathrm{w}$ sampai Periode N. 


$$
\begin{aligned}
f_{w-1}=Z_{v w-1}+f_{v-1} \quad & \text { Pemesanan sebelum pemesanan- } \\
& \text { terakhir harus dilakukan pada Periode } \\
& \mathrm{v} \text { untuk memenuhi permintaan dari } \\
& \text { Periode sampai Periode } \mathrm{w}-1 . \\
& \text { Pemesanan yang pertama harus } \\
& \text { dilakukan pada Periode 1 untuk } \\
& \text { memenuhi permintaan dari Periode } 1 \\
& \text { sampai Periode } \mathrm{u}-1 .
\end{aligned}
$$

Dari perhitungan dengan menggunakan model program dinamis, kemudian di bandingkan dengan prosedur Economic Order Quantity (EOQ). Prosedur untuk memperoleh jumlah pemesanan bahan baku yang optimum bila terdapat incremental discount dan dengan mempertimbangkan kapasitas gudang bahan dengan tujuan meminimumkan biaya total persediaan (total cost of inventory) dapat dijelaskan dengan langkah-langkah sebagai berikut:

1. Hitung $Q^{*}$ sesuai Pers (4) pada setiap price break quantity (tingkat unit biaya).

2. Bandingkan $Q^{*}$ dengan $U$ (batas jumlah bahan yang dipesan di mana terjadi perubahan tingkat unit harga. Jika $Q^{*}$ berada pada interval $U$ dan lebih kecil sama dengan kapasitas berarti $Q^{*}$ valid.

3. Hitung Total Annual Cost (TAC) untuk setiap $Q^{*}$ yang valid dan semua $U$ yang mungkin dengan syarat lebih kecil sama dengan kapasitas.

4. Bandingkan hasil perhitungan TAC untuk $Q^{*}$ yang valid dengan TAC untuk semua nilai $U$ yang mungkin.

5. Pilihlah jumlah pemesanan $(Q)$ yang memberikan nilai TAC paling minimum.

Perhitungan EOQ pada setiap price break quantity pada Pers (4).

$\boldsymbol{Q} *=\frac{\sqrt{2 \mathrm{DC}}}{I P \boldsymbol{j}}$

Pers (4)

\section{Hasil dan Pembahasan}

Percobaan numerik dilakukan dengan melakukan perencanaan pemesanan bahan baku selama 12 bulan dengan jumlah permintaan bahan baku ditunjukkan pada Tabel 1. Biaya pesan Rp. 5000,00 per sekali pesan, fraction biaya simpan adalah $1 \%$ per bulan (12\% per tahun) dari harga satu unit, harga perunit untuk pembelian 1-100 adalah Rp. 10.000, untuk pembelian 101-200 adalah Rp. 9.500 dan untuk pembelian diatas 200 adalah Rp. 9.000. Kapasitas gudang sebesar 250 .

Tabel 1 jumlah permintaan bahan baku selama 12 bulan

\begin{tabular}{lllllllllllll}
\hline Bulan & 1 & 2 & 3 & 4 & 5 & 6 & 7 & 8 & 9 & 10 & 11 & 12 \\
\hline Permintaan & 8 & 20 & 56 & 45 & 35 & 40 & 12 & 30 & 84 & 45 & 35 & 40 \\
\hline
\end{tabular}

Langkah-langkah penyelesaian Algoritma WW dengan batasan kapasitas gudang ini adalah sebagai berikut:

1. Hitung matriks total biaya variabel (biaya pesan dan biaya simpan) sesuai dengan Pers (2) untuk seluruh alternatif order di seluruh horizon perencanaan. Alternatif pemenuhan order $\left(\mathrm{Q}_{\mathrm{ce}}\right)$ dapat dilihat pada Tabel 2. 
Tabel 2 Alternatif pemenuhan order $\left(Q_{\mathrm{ce}}\right)$

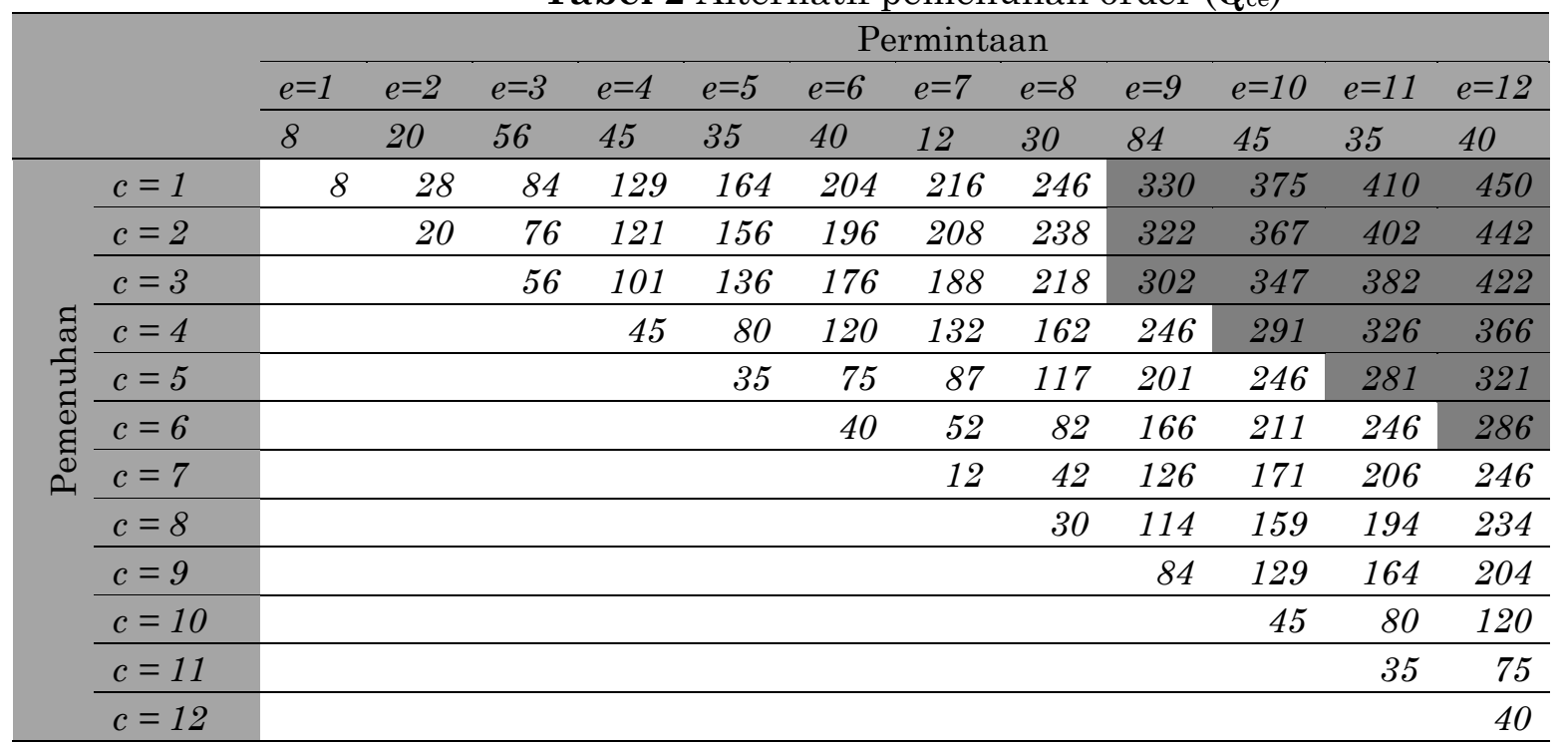

Contoh perhitungan matriks total biaya variabel

$\mathrm{Z}_{11}=5000+((0,01 \times 10000) \times(8-8))+8 \times 10000=85000$

$\left.\mathrm{Z}_{12}=5000+((0,01 \times 10000) \times(28-28+28-8))\right)+28 \times 10000=287000$

$\left.\mathrm{Z}_{13}=5000+((0,01 \times 10000) \times(84-84+84-28+84-8))\right)+84 \times 10000=858200$

$\left.\mathrm{Z}_{14}=5000+((0,01 \times 9500) \times(129-129+129-84+129-28+129-8))\right)+129 \times 9500=$ 1255865

$\left.\mathrm{Z}_{15}=5000+((0,01 \times 9500) \times(164-164+164-129+164-84+164-28+164-8))\right)+164$ x $9500=1601665$

$\mathrm{Z}_{16}=5000+((0,01 \times 9000) \times(204-204+204-164+164-129+164-84+164-28+164-$ $8)))+204 \times 9000=1895630$

$\mathrm{Z}_{17}=5000+((0,01 \times 9000) \times(216-216+216-204+216-164+216-129+216-84+$ $216-28+216-8)))+216 \times 9000=2010110$

$\mathrm{Z}_{18}=5000+((0,01 \times 9000) \times(246-246+246-216+246-204+246-164+246-129+$ $246-84+246-28+246-8)))+246 \times 9000=2299010$

$\mathrm{Z}_{19}=$ Tidak di hitung karena nilai $\mathrm{Q}_{19}$ melebihi kapasitas gudang $(330>250)$

$\mathrm{Z}_{110}=$ Tidak di hitung karena nilai $\mathrm{Q}_{110}$ melebihi kapasitas gudang $(375>250)$

$\mathrm{Z}_{111}=$ Tidak di hitung karena nilai $\mathrm{Q}_{111}$ melebihi kapasitas gudang $(410>250)$

$\mathrm{Z}_{112}=$ Tidak di hitung karena nilai $\mathrm{Q}_{112}$ melebihi kapasitas gudang $(450>250)$

Rekapitulasi perhitungan total biaya variabel dapat dilihat pada tabel 3.

2. Memeriksa batasan pada $Q_{c e}$ bila order dilakukan pada Periode $c$ untuk memenuhi permintaan Periode $c$ sampai Periode $e$ tidak boleh melebihi kapasitas gudang. Berdasarkan Pers (2), Tabel 2 menunjukkan Alternatif pemenuhan order $\left(Q_{\mathrm{ce}}\right)$ di ketahui bahwa $\mathrm{Q}_{19}, \mathrm{Q}_{110}, \mathrm{Q}_{111}, \mathrm{Q}_{112}$ melebihi kapasitas gudang (250). Pada $\mathrm{Q}_{19}$ apabila pemesanan dilakukan pada periode 1 untuk memenuhi permintaan periode 1 sampai periode 9 jumlah pemesanan sebesar 330 , nilai ini menunjukkan bahwa $Q_{19}$ melebihi kapasitas gudang sebesar 250 (330>250). Pada $\mathrm{Q}_{110}$ apabila pemesanan dilakukan pada periode 1 untuk memenuhi permintaan periode 1 sampai periode 10 jumlah pemesanan sebesar 375 , nilai ini 
menunjukkan bahwa $Q_{110}$ melebihi kapasitas gudang sebesar 250 (375>250). Pada Q111 apabila pemesanan dilakukan pada periode 1 untuk memenuhi permintaan periode 1 sampai periode 11 jumlah pemesanan sebesar 410, nilai ini menunjukkan bahwa Q 111 melebihi kapasitas gudang sebesar 250 (410>250). Serta pada $Q_{112}$ apabila pemesanan dilakukan pada periode 1 untuk memenuhi permintaan periode 1 sampai periode 12 jumlah pemesanan sebesar 450, nilai ini menunjukkan bahwa $Q_{112}$ melebihi kapasitas gudang sebesar 250 (450>250). Alternatif pemenuhan order $\mathrm{Q}_{19}, \mathrm{Q}_{110}, \mathrm{Q}_{111}, \mathrm{Q}_{112}, \mathrm{Q}_{29}, \mathrm{Q}_{210}, \mathrm{Q}_{211}, \mathrm{Q}_{212}, \mathrm{Q}_{39}, \mathrm{Q}_{310}, \mathrm{Q}_{311}$, $\mathrm{Q}_{312}, \mathrm{Q}_{410}, \mathrm{Q}_{411}, \mathrm{Q}_{412}, \mathrm{Q}_{511}, \mathrm{Q}_{512}$ dan $\mathrm{Q}_{612}$ tidak dilakukan perhitungan biaya variabel seperti ditunjukkan pada Tabel 3.

Tabel 3 Rekapitulasi perhitungan total biaya variable dalam ribuan

\begin{tabular}{|c|c|c|c|c|c|c|c|c|c|c|c|c|c|}
\hline & & \multicolumn{12}{|c|}{ Permintaan } \\
\hline & & $e=1$ & $e=2$ & $e=3$ & $e=4$ & $e=5$ & $e=6$ & $e=7$ & $e=8$ & $e=9$ & $e=10$ & $e=11$ & $e=12$ \\
\hline & & 8 & 20 & 56 & 45 & 35 & 40 & 12 & 30 & 84 & 45 & 35 & 40 \\
\hline \multirow{12}{*}{ 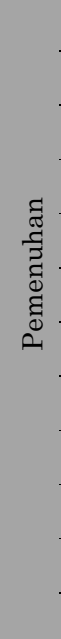 } & $c=1$ & 85,0 & 287,0 & 858,2 & $1.255,9$ & $1.601,7$ & $1.895,6$ & $2.010,1$ & $2.299,0$ & & & & \\
\hline & $c=2$ & & 205,0 & 770,6 & $1.168,4$ & $1.510,8$ & $1.906,0$ & $1.919,4$ & $2.205,6$ & & & & \\
\hline & $c=3$ & & & 565,0 & 968,8 & $1.307,9$ & $1.699,3$ & $1.817,9$ & $2.006,0$ & & & & \\
\hline & $c=4$ & & & & 455,0 & 808,5 & $1.155,9$ & $1.273,3$ & $1.569,7$ & $2.281,2$ & & & \\
\hline & $c=5$ & & & & & 355,0 & 759,0 & 881,4 & $1.131,1$ & $1.858,1$ & $2.283,4$ & & \\
\hline & $c=6$ & & & & & & 405,0 & 526,2 & 832,2 & $1.612,8$ & $1.949,4$ & $2.280,1$ & \\
\hline & $c=7$ & & & & & & & 125,0 & 428,0 & $1.220,8$ & $1.661,1$ & $1.901,6$ & $2.279,6$ \\
\hline & $c=8$ & & & & & & & & 305,0 & $1.096,0$ & $1.532,0$ & $1.874,5$ & $2.150,5$ \\
\hline & $c=9$ & & & & & & & & & 845,0 & $1.234,8$ & $1.573,9$ & $1.862,2$ \\
\hline & $c=10$ & & & & & & & & & & 455,0 & 808,5 & $1.155,9$ \\
\hline & $c=11$ & & & & & & & & & & & 355,0 & 759,0 \\
\hline & $c=12$ & & & & & & & & & & & & 405,0 \\
\hline
\end{tabular}

3. Berdasarkan Pers (3), langkah berikutnya adalah Menghitung $f_{e}$ sebagai biaya minimum yang mungkin dalam Periode 1 sampai Periode 12 , dengan asumsi tingkat persediaan di akhir Periode $e$ adalah nol. biaya minimum yang mungkin dapat dihitung sebagai berikut:

$f_{0}=0$

$f_{1}=\operatorname{Min}\left\{Z_{11}+f_{0}\right\}=\operatorname{Min}\{85.000\}=85.000$ untuk $Z_{11}+f_{0}$.

$f_{2}=\operatorname{Min}\left\{Z_{12}+f_{0}, Z_{22}+f_{1}\right\}=\operatorname{Min}\{287.000+0,205.000+85.000\}=287.000$ untuk $Z_{12}+f_{0}$.

$f_{3}=\operatorname{Min}\left\{Z_{13}+f_{0}, Z_{23}+f_{1}, Z_{33}+f_{2}\right\}=\operatorname{Min}\{858.200,855600,852000\}=852000$ untuk $Z_{33}+f_{2}$.

$f_{4}=\operatorname{Min}\left\{Z_{14}+f_{0}, Z_{24}+f_{1}, Z_{34}+f_{2}, Z_{44}+f_{3}\right\}=\operatorname{Min}\{1.255 .865,1.253 .370,1.255 .775$, $1.307 .000\}=1.253 .370$ untuk $Z_{24}+f_{1}$.

$f_{5}=\operatorname{Min}\left\{Z_{15}+f_{0}, Z_{25}+f_{1}, Z_{35}+f_{2}, Z_{45}+f_{3}, Z_{55}+f_{4}\right\}=\operatorname{Min}\{1601665,1595845$, $1594925,1660500,1608370\}=1594925$ untuk $Z_{35}+f_{2}$.

$f_{6}=1895630$ untuk $Z_{16}+f_{0}$

$f_{7}=2004390$ untuk $Z_{27}+f_{1}$

$f_{8}=2290590$ untuk $Z_{28}+f_{1}$

$f_{9}=3100370$ untuk $Z_{89}+f_{7}$

$f_{10}=3525365$ untuk $Z_{710}+f_{6}$

$f_{11}=3797200$ untuk $Z_{711}+f_{6}$ 
$f_{12}=4152740$ untuk $Z_{912}+f_{8}$

Rekapitulasi perhitungan biaya minimum dapat dilihat pada Tabel 4,

Tabel 4 Rekapitulasi perhitungan biaya minimum dalam ribuan

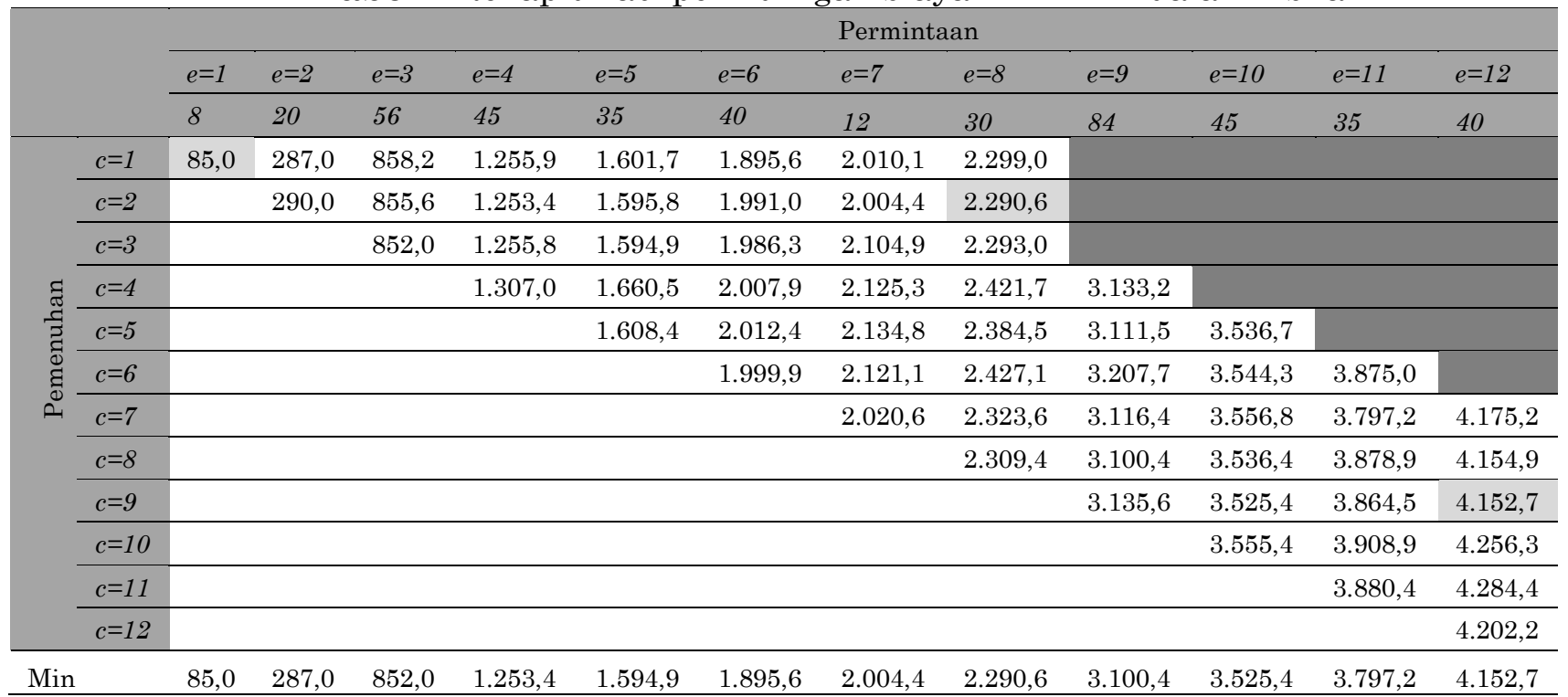

4. Hasil perhitungan menunjukkan bahwa solusi optimal dengan biaya Rp. 4.152.740 untuk $Z_{912}+f_{8}$. Pemesanan dilakukan pada periode 9 untuk memenuhi permintaan pada periode 9 sampai dengan 12, yaitu sebesar 204 unit. Pemesanan dilakukan pada periode 2 untuk memenuhi permintaan pada periode 2 sampai dengan 8, yaitu sebesar 238 unit. Pemesanan dilakukan pada periode 1 untuk memenuhi permintaan pada periode 1, yaitu sebesar 8 unit.

Studi numerik jumlah perencanaan pemesanan bahan baku selama 12 bulan juga dilakukan dengan menggunakan Economic Order Quantity (Q*). Perhitungan $Q^{*}$ dilakukan dengan menggunakan Pers (4). Perhitungan total biaya persediaan tahunan dapat dihitung menggunakan Pers (1). Rekapitulasi perhitungan $\mathrm{Q}^{*}$ untuk incremental diskon dan batasan kapasitas dapat dilihat pada Tabel 5 .

Tabel 5 Rekapitulasi perhitungan $\mathrm{Q}^{*}$ untuk incremental diskon dan batasan kapasitas

\begin{tabular}{ccccc}
\hline \multicolumn{2}{c}{ Harga } & Kuantitas & EOQ $\left(Q^{*}\right)$ & Keterangan \\
\hline $\mathrm{Rp}$ & 10.000 & $1-100$ & 62 & Valid \\
\hline $\mathrm{Rp}$ & 9.500 & $101-200$ & 63 & Tidak Valid \\
\hline $\mathrm{Rp}$ & 9.000 & $>200$ & 65 & Tidak Valid \\
\hline
\end{tabular}

Dari Tabel 5, dilakukan perhitungan Total Annual Cost (TAC) untuk menentukan nilai TAC paling minimum. Perhitungan Total Annual Cost (TAC) dapat dihitung berdasarkan Pers (1). Rekapitulasi perhitungan Total Annual Cost (TAC) untuk $Q^{*}$ valid dan tiap U yang mungkin dapat dilihat pada Tabel 6.

Dari perhitungan Total Annual Cost (TAC) Tabel 6 didapatkan Q* yang minimal dengan jumlah pemesanan sebesar 62 unit dengan jumlah frekwensi pesan 
sebanyak 8 kali pesan, jumlah persediaan sebesar 456 unit dan Jumlah Pembelian sebesar 496 unit dengan Total Annual Cost (TAC) sebesar Rp. 4.545.040. Perbandingan Total Annual Cost (TAC) metode EOQ dengan algoritma WW didapatkan perbandingan untuk biaya algoritma WW Rp. 4.152.740 dan Total Annual Cost (TAC) EOQ sebesar Rp. 4.545.040. dari perbandingan tersebut didapatkan algoritma WW dapat meminimalisasi total biaya persediaan dibandingkan dengan menggunakan EOQ. Prosentase penghematan adalah Rp. 392.300 atau sebesar $9 \%$.

Tabel 6 Rekapitulasi perhitungan Total Annual Cost (TAC) untuk Q* valid

\begin{tabular}{cccccc}
\hline EOQ $\left(\mathrm{Q}^{*}\right)$ & $\begin{array}{c}\text { Frekuensi } \\
\text { Pesan }\end{array}$ & $\begin{array}{c}\text { Jumlah } \\
\text { persedian }\end{array}$ & $\begin{array}{c}\text { Jumlah } \\
\text { Pembelian }\end{array}$ & \multicolumn{2}{c}{ TAC } \\
\hline 62 & 8 & 456 & 496 & $\mathrm{Rp}$ & 4.545 .040 \\
\hline 101 & 5 & 790 & 505 & $\mathrm{Rp}$ & 4.897 .550 \\
\hline 201 & 3 & 1577 & 603 & $\mathrm{Rp}$ & 5.583 .930 \\
\hline
\end{tabular}

\section{Simpulan}

Hasil perhitungan menggunakan algoritma Wagner Within (WW) dengan incremental discount dan kendala kapasitas gudang dapat memberikan solusi optimal dengan biaya Rp. 392.300 atau sebesar 9\%. Pemesanan dilakukan pada periode 9 untuk memenuhi permintaan pada periode 9 sampai dengan 12, yaitu sebesar 204 unit. Pemesanan dilakukan pada periode 2 untuk memenuhi permintaan pada periode 2 sampai dengan 8, yaitu sebesar 238 unit. Pemesanan dilakukan pada periode 1 untuk memenuhi permintaan pada periode 1 , yaitu sebesar 8 unit. Penelitian selanjutnya dapat mengembangkan algoritma Wagner Within (WW) untuk kasus multi item produk.

\section{Daftar Notasi}

$\mathrm{TAC}=$ Total biaya persediaan tahunan

$\mathrm{OC}=$ total biaya pemesanan

$\mathrm{PC}=$ total biaya pembelian

$\mathrm{IC}=$ total biaya penyimpanan

$\mathrm{C}=$ biaya pesan

I = Fraction biaya simpan (dalam \%)

$\mathrm{Pj}=$ Biaya Pembelian pada kuantitas $\mathrm{j}$

$\mathrm{Dk}=$ permintaan pada periode $\mathrm{k}$

$Q^{*}=$ Jumlah pemesanan Ekonomis

$\mathrm{D}=$ Permintaan 1 tahun

$\mathrm{C}=$ Biaya Pesan

$D k=$ permintaan pada periode $k$

\section{Referensi}

[1] J. E. Biegel, Pengendalian produksi suatu pendekatan kuantitatif. Jakarta: Akademika Pressindo, 1992.

[2] D. Sipper and R. L. Bulfin, Production: planning, control, and integration: McGraw-Hill Science, Engineering \& Mathematics, 1997.

[3] S. N. Bahagia, Sistem Inventori. Bandung: Penerbit ITB, 2006. 
[4] J. T. Richard, Principles of inventory and materials management: PTR Prentice Hall, 1994.

[5] E. A. Elsayed and T. O. Boucher, Analysis and control of production systems: Prentice Hall, 1994.

[6] J. Heizer, Operations Management, 11/e: Pearson Education India, 2016.

[7] H. Prasetyo, M. T. Nugroho, and A. Pujiarti, "Pengembangan Model Persediaan Bahan Baku dengan Mempertimbangkan Waktu Kadaluwarsa dan Faktor Unit Diskon," Jurnal Ilmiah Teknik Industri, vol. 4, pp. 115-122, 2006.

[8] T. A. I. Puspita, E. Suryani, and R. Prasetianto, "Penerapan Economic Order Quantity (EOQ) Model dengan Faktor Diskon yang Diintegrasikan pada ADempiere untuk Optimasi Biaya Persediaan di KUD Dau Malang," Jurnal Teknik ITS, vol. 1, pp. A579-A584, 2012.

[9] M. Djunaidi, S. Nandiroh, and I. O. Marzuki, "Pengaruh perencanaan pembelian bahan baku dengan model EOQ untuk multiitem dengan all unit discount," Jurnal Ilmiah Teknik Industri, vol. 4, pp. 86-94, 2005.

[10] S. Suryajaya, T. Octavia, and G. A. Widyadana, "Model Persediaan Bahan Baku Multi Item dengan Mempertimbangkan Masa Kadaluwarsa, Unit Diskon dan Permintaanyang Tidak Konstan," Jurnal Teknik Industri, vol. 14, pp. 97-105, 2012.

[11] E. Kusrini, "Sistem Persediaan Multi Item dengan Kendala Investasi dan Luas Gudang," Jurnal Teknoin, vol. 10, 2005.

[12] H. M. Wagner and T. M. Whitin, "Dynamic version of the economic lot size model," Management science, vol. 5, pp. 89-96, 1958.

[13] P. Eisenhut, "A dynamic lot sizing algorithm with capacity constraints," AIIE transactions, vol. 7, pp. 170-176, 1975.

[14] D. M. Utama, "Penentuan Lot Size Pemesanan Bahan Baku Dengan Batasan Kapasitas Gudang," Jurnal Ilmiah Teknik Industri, vol. 15, pp. 64-68, 2016.

[15] W. S. Wijaya and I. G. A. Widyadana, "Penentuan Ukuran Pemesanan Material dengan Memperhatikan Decay Inventory dan Quantity Unit Discount," Jurnal Titra, vol. 1, pp. 57-62, 2013.

[16] W. N. Madinah, Y. Sumantri, and W. Azlia, "Penentuan Metode Lot Sizing Pada Perencanaan Pengadaan Bahan Baku Kikir Dan Mata Bor (Studi Kasus: PT X, Sidoarjo)," Jurnal Rekayasa dan Manajemen Sistem Industri, vol. 3, pp. p505$515,2015$.

[17] H. K. W. Mbota, C. F. M. Tantrika, and A. Eunike, "Perencanaan Persediaan Bahan Baku Dan Bahan Bakar Dengan Dynamic Lot Sizing (Studi Kasus: PT Holcim Indonesia Tbk, Tuban Plant)," Jurnal Rekayasa dan Manajemen Sistem Industri, vol. 3, pp. p178-188, 2015. 